\title{
WestVirginiaUniversity.
}

Department of Economics

Working Paper Series

\section{Do National Basketball Association Players Need Higher Salaries to Play in High Tax States? Evidence from Free Agents}

Candon Johnson

Joshua Hall

Working Paper No. 17-11

This paper can be found at the College of Business and Economics Working Paper Series homepage: 


\title{
Do National Basketball Association Players Need Higher Salaries to Play in High Tax States? Evidence from Free Agents
}

\author{
Candon Johnson \\ Department of Economics \\ College of Business and Economics \\ West Virginia University \\ cjohns77@mix.wvu.edu \\ Joshua Hall \\ Department of Economics \\ College of Business and Economics \\ West Virginia University \\ joshua.hall@mail.wvu.edu
}

\begin{abstract}
This paper investigates the impact of taxes on the salaries received by National Basketball Association free agents from 2010-2014. High state income tax rates affect the after-tax income received by players from their team as well as on any ancillary income. Using data on 576 free agents, we find statistically significant evidence that free agents signing in high tax states receive higher salaries, ceteris paribus. Our results suggest that a one-unit increase in the average tax rate experienced by a free agent in a state leads to free agent salaries being over $\$ 60,000$ higher.
\end{abstract}

JEL Codes: H20, H24, H71

Keywords: Tiebout; taxation; National Basketball Association 


\section{Do National Basketball Association Players Need Higher Salaries to Play in High Tax States? Evidence from Free Agents}

\section{Introduction}

This study investigates the impact of state tax rates on the salaries paid to National Basketball Association (NBA) free agents. In doing so, we build upon two distinct strands of literature. The first strand is on the role that taxes play in where individuals locate (Cebula, 1974; Cebula, 1990; Saltz, 1998; Alfonso 2015). This literature largely finds that income taxation does affect where individuals' reside on the margin, especially for high-income taxpayers who may have the resources and skills to locate in a number of states. For example, Alfonso (2015) looks at the legal residence of members of the military and finds that state income taxes deter residency and that this effect is strengthened as income rises. The second strand is the determination of salaries in the National Basketball Association (NBA). The primary focus of this literature has been wage discrimination, either against African-Americans (Kahn and Sherer, 1998; Gius and

Johnson, 1998; Hamilton, 1997) or foreign-born players (Eschker et al. 2004; Hoffer and Freidel, 2014).

We bring together these literatures to better understand the responsiveness to taxation in different institutional environments. Like baseball players, professional basketball players are different than most workers in that their profession does not exist in all US states. Although the NBA has thirty teams, they are only located in twenty-two states (plus Canada). The lack of professional work opportunities in zero income tax states such as Alaska, Nevada, South Dakota, Washington and Wyoming, combined with a limited number of roster spots in zero income tax states like Florida and Texas, means that many NBA free agents are likely to accept positions in 
high income tax states like California. In equilibrium, however, they should want to be compensated for their higher taxes through a higher salary. Using a sample of Major League Baseball (MLB) free agents, Ross and Dunn (2007) find that this is the case for Major League Baseball (MLB) free agents. Unlike MLB, however, the NBA has a salary cap and teams might find themselves limited in being able to pay higher salaries in order to attract free agents, other things being equal. Our analysis therefore both complements and extends previous work on the responsiveness to state income taxation and the salaries of professional athletes.

\section{Data and Empirical Approach}

Following the literature on NBA salaries (Hoffer and Friedel, 2014) and taxes on MLB free agents (Ross and Dunn, 2007), we estimate using Ordinary Least Squares (OLS) a standard salary estimation equation,

$$
S=X \beta+\gamma \theta+\varepsilon
$$

The dependent variable, $S$, is the salary for each NBA free agent from 2010-2014. Data on the 576 free agents over this period were obtained from the NBA's website 'Free Agent Tracker.' This data source only lists free agents that hit the market and does not include those who signed extensions before becoming free agents. Out of the 576 free agents, 352 players changed teams. The free agent data was then matched with salary data collected from Bender (2016), a widely used source in the sports economic literature (Berri and Jewell, 2004). $X$ is a vector of player characteristics such as points and rebounds, $\gamma$ is the average income tax rate of the player, and $\varepsilon$ is the error term.

The basketball statistics we employ as controls are all standard in the literature (see, for example, Gius and Johnson (2010) and Hoffer and Friedel (2014)). These measured on-the-court 
statistics presumably reflect much of what NBA General Managers are looking for when signing free agents to contracts. We include Points Per Game, Rebounds Per Game, Assists Per Game, Steals Per Game, and Blocks Per Game, collected from Basketball-Reference.com. These variables, except for Steals Per Game, is expected to be positively related to salary. Steals Per Game has been found to be negatively related to salary (Hoffer and Friedel, 2014), presumably because steals represent risky behavior that might be bad on net for team success. We also include the free agent's age (Age) and also include a squared term (Age Squared) to see if at some point age becomes a detriment, other things being equal. The final player variables we include are binary variables equaling one if yes and zero otherwise if the player is a Restricted Free Agent and if they return (Resign) to their original team after testing the free agency waters. To these player variables, we also add winning percentage of the signing team (Team Winning Percentage) to capture the fact the fact that players might be willing to take a discount to play with a winning team.

To measure tax differences across states, we follow Ross and Dunn (2014) and use the NBER TAXSIM software (version 9) to calculate what they call the Average Tax Rate. We use the free agent's salary in the year following free agency to estimate federal and state tax liability and dived that by total income. It is necessary to do this, because state taxes are deductible from federal taxable income for those who itemize. Due to the difficulty in determining all aspects of individual free agents' tax returns (such as charitable donations, dependents, etc.), we assumed that each player was married filing jointly and that their spouse had zero income in the year of the move. All other inputs were set to zero. Descriptive statistics for Average Tax Rate and all other variables can be found in Table 1. 


\section{Empirical Findings}

Regression results are shown in Table 2. Two specifications are provided. The first specification includes all variables except Restricted Free Agent, while the second includes. The models perform as expected, explaining 63 percent of the variation in first-year free agent salaries over this time period. In terms of our variable of interest, Average Tax Rate is positive and statistically significant in both specifications. Looking at the coefficient on Average Tax Rate in specification 2, we observe that a one percentage point increase in a player's Average Tax Rate in a state is associated with a $\$ 60,623$ higher salary required to induce them to sign a contract.

With respect to the variables related to player attributes, all have the expected sign and the majority are statistically significant at conventional levels. Not surprisingly, players who scored more Points Per Game received higher first-year free agent salaries, other things equal. The same is true for Rebounds Per Game, Assists Per Game, and Blocks Per Game. Similar to Hoffer and Friedel (2014), we find steals to be negatively related to salaries, but not in a statistically significant manner. Age and Age Squared are both statistically significant, with Age being positive and Age Squared negatively related to salary. This suggests that experience is good, but peaks at approximately 27 years of age. Team Winning Percentage is not statistically significant. Restricted Free Agent is positive and statistically significant, suggesting that restricted free agents made higher salaries during this period, perhaps as other teams attempted to make so-called 'poison pill' offers to take up cap space on rival teams, or attempted to make an offer that cannot be matched by the player's current team. Finally, there is no evidence that players give a 'home town discount' when resigning with their original team, as the Resign is positive and statistically significant across both specifications. 


\section{Conclusion}

We find evidence that the average tax rate is expected to have in a state positively affects their salary. A one-unit change in Average Tax Rate is associated with over a $\$ 60,000$ increase in firstyear salary for NBA free agents. Given that the NBA has a salary cap, this finding potentially has important implications for NBA teams trying to sign free agents and stay under the salary cap.

\section{References}

Afonso, W. 2015. “State Income Taxes and Military Service Members’ Legal Residency Choices." Contemporary Economic Policy 33: 334-350.

Bender, P. 2016. "Patricia’s Various Basketball Stuff.” https://www.eskimo.com/ pbender/

Berri, D., and R. Jewell. 2004. "Wage Inequality and Firm Performance: Professional Basketball’s Natural Experiment.” Atlantic Economic Journal 32: 130-139.

Cebula, R. 1974. "Interstate Migration and the Tiebout Hypothesis: An Analysis According to Race, Sex and Age.” Journal of the American Statistical Association 69: 876-879.

Cebula, R. 1990. "Brief Empirical Note on the Tiebout Hypothesis and State Income Tax Policies.” Public Choice 67: 87-89.

Eschker, E., S. Perez, and M. Siegler. 2004. "The NBA and the Influx of International Basketball Players.” Applied Economics 36: 1009-1020.

Gius, M., and D. Johnson. 1998. "An Empirical Investigation of Wage Discrimination in Professional Basketball.” Applied Economics Letters 5: 703-705.

Hamilton, B. 1997. "Racial Discrimination and Professional Basketball Salaries in the 1990s." Applied Economics 29: 287-296.

Hoffer, A., and R. Freidel. 2014. "Does Salary Discrimination Persist for Foreign Athletes in the NBA?” Applied Economics Letters 21: 1-5.

Kahn, L., and P. Sherer. 1988. "Racial Differences in Professional Basketball Players' Compensation.” Journal of Labor Economics 6: 40-61.

Ross, J., and R. Dunn. 2007. "The Income Tax Responsiveness of the Rich: Evidence From Free Agent Major League Baseball All-Stars.” Contemporary Economic Policy 25: 639-648.

Saltz, I. 1998. "State Income Tax Policy and Geographic Labour Force Mobility in the United States.” Applied Economics Letters 5: 599-601. 
Table 1. Descriptive statistics

\begin{tabular}{lrrrr}
\hline \multicolumn{1}{c}{ Variable } & \multicolumn{1}{c}{ Mean } & Std. Dev. & Minimum & Maximum \\
\hline Salary & $\$ 3,913,782$ & $\$ 3,860,268$ & $\$ 71,951$ & $\$ 20,644,400$ \\
Average Tax Rate & 38.01 & 4.78 & 8.83 & 48.41 \\
Team Winning & 0.52 & 0.15 & 0.11 & 0.81 \\
Percentage & 28.61 & 3.89 & 21 & 39 \\
Age & 833.53 & 230.63 & 441 & $1,521.00$ \\
Age Squared & 0.39 & 0.49 & 0 & 1 \\
Resign & 8.46 & 4.96 & 0.5 & 29.7 \\
Points Per Game & 3.65 & 2.3 & 0 & 12.4 \\
Rebounds Per Game & 1.83 & 1.64 & 0 & 10.7 \\
Assists Per Game & 0.66 & 0.37 & 0 & 2.4 \\
Steals Per Game & 0.43 & 0.43 & 0 & 2.5 \\
Blocks Per Game & 0.17 & 0.38 & 0 & 1 \\
Restricted & & & & 0.4 \\
\hline
\end{tabular}

Note: Calculated for all 576 NBA free agents in sample. 
Table 2. OLS estimates of NBA player characteristics and average tax rate on salaries

\begin{tabular}{|c|c|c|c|c|}
\hline Variable & (1) & & (2) & \\
\hline Average Tax Rate & $\begin{array}{r}62,074.2 \\
(23,729.3)\end{array}$ & $* * *$ & $\begin{array}{r}60,623.7 \\
(23,856.8)\end{array}$ & $* *$ \\
\hline Team Winning Percentage & $\begin{array}{l}-494,846.7 \\
(709370.4)\end{array}$ & & $\begin{array}{r}-533,389.9 \\
(710,078.4)\end{array}$ & \\
\hline Age & $\begin{array}{r}913,274.4 \\
(358153.6)\end{array}$ & $* *$ & $\begin{array}{l}1,148,624.0 \\
(361,127.2)\end{array}$ & $* * *$ \\
\hline Age Squared & $\begin{array}{r}-15,918.5 \\
(6,096.3)\end{array}$ & $* * *$ & $\begin{array}{r}-19,478.5 \\
(6,125.9)\end{array}$ & $* * *$ \\
\hline Resign & $\begin{array}{l}1,251,463.0 \\
(220,867.7)\end{array}$ & $* * *$ & $\begin{array}{l}1,168,125.0 \\
(228,588.3)\end{array}$ & $* * *$ \\
\hline Points Per Game & $\begin{array}{l}415,265.0 \\
(40,464.5)\end{array}$ & $* * *$ & $\begin{array}{l}414,605.0 \\
(40,460.4)\end{array}$ & $* * *$ \\
\hline Rebounds Per Game & $\begin{array}{l}303,155.8 \\
(84,151.9)\end{array}$ & $* * *$ & $\begin{array}{r}310,192.6 \\
(84,142.8) \\
251\end{array}$ & $* * *$ \\
\hline Assists Per Game & $\begin{array}{r}240,294.4 \\
(103,935.6)\end{array}$ & $* *$ & $\begin{array}{r}058.0 \\
(104,032.0)\end{array}$ & $* *$ \\
\hline Steals Per Game & $\begin{array}{r}-210,637.4 \\
(412,083.7)\end{array}$ & & $\begin{array}{r}-279,342.3 \\
(414,849.1)\end{array}$ & \\
\hline Blocks Per Game & $\begin{array}{r}992,179.7 \\
(483,742.2)\end{array}$ & $* *$ & $\begin{array}{r}989,311.6 \\
(485,058.9)\end{array}$ & $* *$ \\
\hline Restricted Free Agent & & & $\begin{array}{r}592,456.9 \\
(310,033.3)\end{array}$ & $*$ \\
\hline $\begin{array}{l}\text { R-squared } \\
\text { F-statistic }\end{array}$ & $\begin{array}{l}0.633 \\
40.69\end{array}$ & & $\begin{array}{l}0.635 \\
37.85\end{array}$ & \\
\hline
\end{tabular}

Note: Absolute value of robust standard errors in parentheses. *, ** and *** indicate significance at the $1 \%, 5 \%$ and $10 \%$ levels, respectively. $\mathrm{N}=576$ in both specifications. Year fixed effects and intercept included in regression but omitted from table for space. 